\title{
Marketing of food and beverage in Brazil: \\ scientific literature review on regulation and self-regulation of advertisements
}

Kassahara A, Sarti FM. Publicidade de alimentos e bebidas no Brasil: revisão de literatura científica sobre regulação e autorregulação de propagandas. Interface (Botucatu). 2018; 22(65):589-602.

The effects of marketing strategies for promotion of foods and beverages have been investigated due to its potential impacts on populations' food choices, particularly among children and adolescents. The paper presents an academic literature review on regulation and self-regulation of food and beverage advertisements in Brazil, based on search performed in electronic databases. Majority of studies were based on law analysis or qualitative study of advertisements. There are sufficient evidences on the need for government regulation of advertisements addressed to children and adolescents complementarily to institutional selfregulation in order to tackle ethical transgressions on food and beverage advertisements identified in Brazil. Additionally, there should be imposition of rigorous penalties for noncompliance to ethical rules and proposition of incentives towards actions encouraging healthy food consumption patterns, in order to comprise an actual system for promotion of public health.

Keywords: Food publicity. Health care coordination and monitoring. Direct-toconsumer advertising.
Os efeitos de estratégias de marketing para promoção de alimentos e bebidas têm sido investigados devido aos potenciais impactos sobre escolhas alimentares populacionais, particularmente entre crianças e adolescentes. $\mathrm{O}$ artigo apresenta revisão de literatura acadêmica sobre regulação e autorregulação de propagandas de alimentos e bebidas no Brasil, baseada em busca realizada em bases de dados eletrônicas. A maioria dos estudos identificados referia-se a análise de legislação ou estudo qualitativo das propagandas. Há evidências de necessidade de regulação das propagandas direcionadas a crianças e adolescentes em complementação ao sistema de autorregulação institucional para combate às transgressões éticas identificadas em propagandas de alimentos e bebidas no Brasil. Adicionalmente, há necessidade de aplicação de penalidades severas para transgressões éticas, assim como incentivos às ações de apoio à alimentação saudável para compor um sistema efetivo de promoção da saúde pública.

Palavras-chave: Publicidade de alimentos. Regulação e fiscalização em saúde. Publicidade direta ao consumidor.
Aline Kassahara(a) Flavia Mori Sarti ${ }^{(b)}$

\footnotetext{
(a) Nutritionista. Rua Bernardo dos Santos 10, alpha 264. São Paulo, SP, Brasil. 05542-000 alinekassahara@me.com (b) Escola de Artes, Ciências e Humanidades, Universidade de São Paulo. São Paulo, SP, Brasil.flamori@usp.br
} 


\section{Introduction}

Recent trends of growth in the prevalence of obesity and related chronic diseases have been associated with nutrition transition processes in diverse countries worldwide, involving reduction in physical activity levels and escalation in availability and consumption of processed foods and beverages, especially regarding items with low nutritional content (soft drinks, sweets, and other processed products with added sugar, salt and fat) ${ }^{1,2}$.

Current studies acknowledge the influence of socioeconomic determinants on population's food preferences and nutrition choices, mainly referring to household, neighborhood and societal characteristics surrounding individuals, and its overlapping synergistic effects ${ }^{3-5}$. Regarding socioeconomic determinants of health, effects of marketing strategies directed towards promotion of foods and beverages have been investigated due to its potential impacts on food choices, particularly among children and adolescents $6-12$.

Considering potential influences of children's food choices on long-term food consumption patterns $7,9,10,13,14$, initiatives have been adopted in diverse countries to monitor, limit or ban advertisement on foods and beverages, especially through mass media communication and on-site at food retail stores ${ }^{9,15-18}$.

In Brazil, regulatory mechanisms on food and beverage advertisements are adopted since 1970s through institutional self-regulation of ethical transgressions monitored by the National Council of Self-Regulatory Publicity (Conselho Nacional de Autorregulamentação Publicitária, CONAR). CONAR is a non-governmental organization responsible for issuing and supervising the Code of Ethics applied to marketing strategies ${ }^{15}$, including recent reviews of specific rules concerning advertisement of food and beverage industry and advertisement of products for children and adolescents ${ }^{19-26}$, published in 2006.

In addition to institutional self-regulation of CONAR, the Brazilian government established a national system for protection of consumers' rights during 1990s, based on Consumers' Defense Code (Código de Defesa do Consumidor, CDC) ${ }^{27}$, supported by Foundation for Consumers' Protection and Defense (Fundação de Proteção e Defesa do Consumidor, PROCON), National Secretary of Justice Ministry (SENACON), and Federal and State Public Ministries ${ }^{28}$.

Along the last decade, national debate on ethical transgressions of food and beverage advertisements reached its pinnacle in Brazil, grounded on polarized discussion about (in)effectiveness of advertisement monitoring through institutional self-regulation and/or need(less) for government regulation to tackle excessive misinformation. A proposal of government regulation on food and beverage advertisements was carried forward by Brazilian Ministry of Health, based on Public Consultation 71/2006, published by National Agency for Health Surveillance (Agência Nacional de Vigilância Sanitária, ANVISA) in order to propose and establish a technical regulation on marketing related to foods and beverages with added sugar, sodium, and saturated and trans fats ${ }^{29}$.

A Resolution of Executive Board of ANVISA (RDC 24/2010) was the main result of Public Consultation 71/2006, intended for government regulation of advertisement of foods and beverages with low nutritional content ${ }^{30}$. The regulation was revoked by $6^{\text {th }}$ Committee of $1^{\text {st }}$ region Federal Regional Court in 2013, due to appeal of Brazilian Association of Food Industry (Associação Brasileira das Indústrias da Alimentação, $A B I A$ ), based on arguments of lack of jurisdiction for imposition of penalties on food and beverage advertisements by ANVISA.

Simultaneously, the National Council for Food and Nutrition Security (Conselho Nacional de Segurança Alimentar e Nutricional, CONSEA) recommended to Brazilian legislative representatives prioritization of law projects related to regulation of processed foods and beverages advertisement in 2013, based on human right for proper nutrition and consumers' right for information ${ }^{31}$; and the National Council for the Rights of Child and Adolescent (Conselho Nacional dos Direitos da Criança $e$ do Adolescente, CONANDA) considered that marketing directed to children is abusive, condemning overexposure of children to advertisement of processed foods and beverages ${ }^{32}$. In sequence, Brazilian Ministry of Health recommended that health professionals inform to children's families negative influences of exposure to processed food and beverage advertisements ${ }^{33}$.

Public health advocacy has been proactive in claiming for improvements related to food and 
beverage advertisement, especially directed to children and youngsters. Civil society organizations have been promoting events and publishing pieces to support debate around regulation (e.g. Agency of News for Children's Rights - Agência de Notícias dos Direitos da Infância, ANDI; Brazilian Institute for Consumers' Defense - Instituto Brasileiro de Defesa do Consumidor, IDEC; and Instituto Alana), questioning extent and usefulness of CONAR self-regulation for monitoring food and beverage advertisements ${ }^{28}$.

In view of current discussion regarding need for regulation or self-regulation of food and beverage advertisements in Brazil, the present paper proposes to perform review of studies published on academic literature, in order to convey information to support evidence-based decision-making processes in policy directed towards promotion of public health. The study seeks to synthesize knowledge expressed in academic literature published in Brazil referring to role of regulation and selfregulation of food and beverage advertisement to offer contributions to the field of nutrition in public health, aiming for improvement of legal frameworks and institutional structures associated with health communication and health promotion.

\section{Methods}

The study presents review of scientific literature on regulation and self-regulation of advertisement of food and beverage in Brazil, performed in electronic databases Scielo, PubMed, Bireme BVS, and Scholar Google.

Studies published in Portuguese or English in peer-reviewed academic journals, scientific meetings, MSc. thesis or PhD. dissertations from 2005 until 2015 were eligible for analysis. Strategy adopted for literature search associated with the subject "regulation or self-regulation of food and beverage advertisement" was based on multiple combinations of keywords selected in Health Sciences Descriptors (DeCS), using Boolean operators "AND" and "OR":

- MEDLINE/PubMed

((("food publicity" [MeSH Terms] OR ("food" [All Fields] AND "publicity" [All Fields]) OR "food publicity" [All Fields]) AND ("Brasil" [All Fields] OR ("Brazil" [MeSH Terms] OR "Brazil" [All Fields]))) AND ("2005/01/01" [PDAT]:"2015/12/31" [PDAT])

- Scielo and Bireme BVS

(propaganda de alimentos OR food advertisement) OR (propaganda de bebidas OR beverage advertisement) AND (regulamentação OR regulation)

Filter: Brasil

Year of publication: 2005-2015

- Scholar Google

(("Regulation of advertisement" OR "Regulamentação da publicidade") AND ("Food advertisement" OR "Propaganda de alimentos") AND ("Brazil" OR "Brasil"))

(("Regulation of advertisement" OR "Regulamentação da publicidade") AND ("Beverage advertisement" OR "Propaganda de bebidas") AND ("Brazil" OR "Brasil"))

("Regulation of advertisement" OR "Regulamentação de propagandas")

(("Food advertisement" OR "Propaganda de alimentos") AND "CONAR")

(("Beverage advertisement" OR "Propaganda de bebidas") AND "CONAR")

Specific period: 2005-2015

Literature review strategy followed methods proposed in Preferred Reporting Items for Systematic Reviews and Meta-Analyses (PRISMA) ${ }^{34}$.

First literature search strategy used to perform literature review identified 198 records and one additional record was obtained through other sources; after exclusion of duplicates and records with 
unsuitable titles, 81 records were screened for abstract analysis. Analysis of abstract showed sixty studies eligible for full-text analysis. Full-texts of 33 studies were excluded of literature review due to theme out of scope of analysis (Flowchart 1).

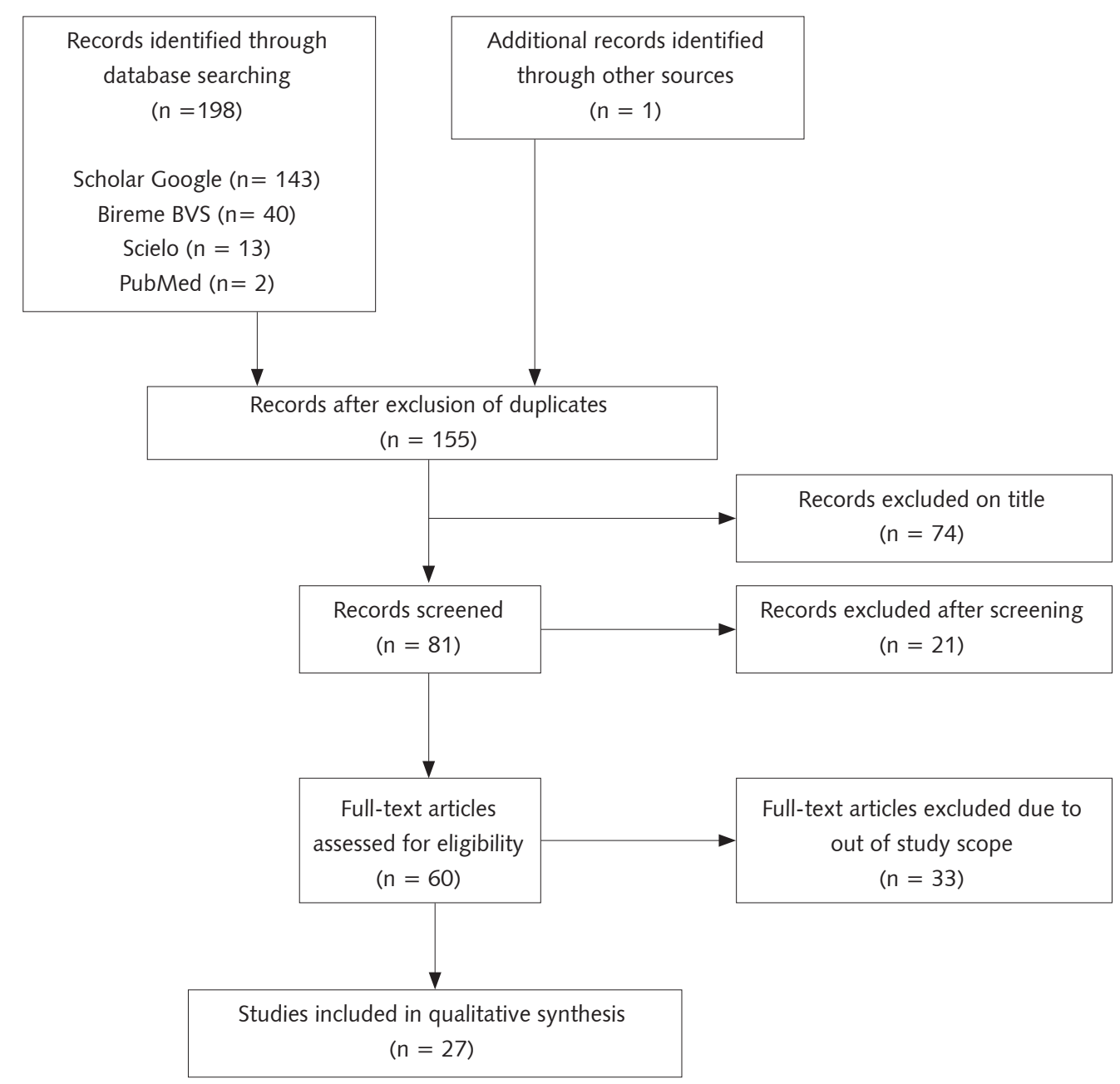

Flowchart 1. Procedures for scientific literature review on regulation and self-regulation of food and beverage advertisements in Brazil. Brazil, 2015.

Source: Authors, based on Moher et al. ${ }^{34}$.

The following inclusion criteria were adopted for literature selection: papers published between 2005 and 2015 in English or Portuguese; complete manuscripts available for analysis on electronic databases; studies based on analysis of legal documents, literature review and/or analysis of primary or secondary data on regulation and self-regulation of food advertisement in Brazil; papers published in peer reviewed academic journals or scientific meetings; and academic works (MSc thesis or PhD dissertations). 
Exclusion criteria for literature selection included: grey literature, manuscripts out of scope of review (regulation and self-regulation of food advertisement in Brazil); studies duplicated; and papers without full-text available for analysis. Screening process of records was based on the criteria described.

The analysis of studies gathered in literature review included qualitative investigation of type of research conducted, principal contents and results presented, and potential targeting or bias in the approach of the subject. Three main directions were identified in approach of the subject: in favor/ against food industry, in favor/against monitoring performed by CONAR, and in favor/against government regulation (including ANVISA).

\section{Results}

Literature search strategy resulted in 27 full-text studies for analysis on food and beverage advertisement regulation and self-regulation in Brazil (Chart 1). Majority of studies were based on law analysis (7) or qualitative study of advertisements (7), especially due to current discussion on legality of food and beverage advertisement regulation by ANVISA.

Chart 1. Results of scientific literature review on regulation and self-regulation of food and beverage advertisements in Brazil, according to year of publication. Brazil, 2015.

\begin{tabular}{|c|c|c|c|}
\hline Title & Year & Method & Findings \\
\hline Lopes et al. ${ }^{35}$ & 2005 & Qualitative study & $\begin{array}{l}\text { Analysis of the content of food and medication advertisements circulated } \\
\text { between November } 2004 \text { and June } 2005 \text { in the state of Goias, showing } \\
\text { the need for advertisements monitoring due to noncompliance with ethical } \\
\text { standards. }\end{array}$ \\
\hline $\begin{array}{l}\text { Fagundes and } \\
\text { Souza }^{36}\end{array}$ & 2007 & Law analysis & $\begin{array}{l}\text { Analysis of the prerogatives related to monitoring of advertisements of } \\
\text { products regulated by health surveillance in Brazil, indicating the lack of } \\
\text { control in the supervision process of advertisements. According to the results } \\
\text { of the Brazilian Public Consultation } 71 / 2006 \text {, the focus of supervision should } \\
\text { be protection of citizens' health. }\end{array}$ \\
\hline $\begin{array}{l}\text { Santos and } \\
\text { Batalha }^{37}\end{array}$ & 2007 & Qualitative study & $\begin{array}{l}\text { Description of the contents of food and beverage advertisements aired in } \\
\text { three open TV channels with high audience between August and September } \\
2005 \text { in the city of Sao Carlos (state of Sao Paulo, Brazil), indicating } \\
\text { significant level of ethical transgressions for processed foods advertisements. } \\
\text { Yet, states that evidences published with experiences from other countries } \\
\text { are inconclusive concerning the linkage between food marketing ban and } \\
\text { discouragement for adoption of unhealthy diets. }\end{array}$ \\
\hline Guimarães $^{38}$ & 2008 & Law analysis & $\begin{array}{l}\text { Comparative analysis of aspects monitored in food advertisements by } \\
\text { CONAR and ANVISA, showing that there are important differences } \\
\text { between characteristics considered by both institutions, since CONAR Code } \\
\text { of Ethics included several items that were not applicable for monitoring } \\
\text { food advertisements. Other countries with government regulation of } \\
\text { advertisement adopt specific regulation for foods and beverages. }\end{array}$ \\
\hline $\begin{array}{l}\text { Pinheiro and } \\
\text { Carvalho } \\
\text { Ca }^{39}\end{array}$ & 2008 & Essay & $\begin{array}{l}\text { Description of historical context referring to social policy in Brazil and its } \\
\text { deployments in the field of food and nutrition, indicating the need for } \\
\text { strengthening government regulation within a strategic framework to } \\
\text { address the ongoing nutrition transition in the country. }\end{array}$ \\
\hline Rebouças $^{40}$ & 2008 & Law analysis & $\begin{array}{l}\text { Comparative analysis of the differences between self-regulatory models } \\
\text { directed to food advertisement adopted in Canada (Québec) and Brazil, } \\
\text { showing that the Canadian model includes social mobilization and the } \\
\text { Brazilian model is supported by the food market cartel. That is, in Brazil, the } \\
\text { focus of debate on food advertisements monitoring was on media funding; } \\
\text { whereas in Canada, it was on food companies reputations. }\end{array}$ \\
\hline
\end{tabular}


Chart 1. continuation

\begin{tabular}{|c|c|c|c|}
\hline Title & Year & Method & Findings \\
\hline Ferraz Junior ${ }^{41}$ & 2009 & Law analysis & $\begin{array}{l}\text { Analysis of the jurisdiction potentially attributable to ANVISA on monitoring } \\
\text { and control of marketing, advertisement and information on foods and } \\
\text { beverages, through administrative acts; indicating the absence of legal } \\
\text { grounds to support its intervention in regulation of food and beverage } \\
\text { advertisements. ANVISA acts are limited to education campaigns due to } \\
\text { legal limits established by Brazilian Constitution regarding interference in the } \\
\text { economic domain. }\end{array}$ \\
\hline $\begin{array}{l}\text { Monteiro and } \\
\text { Castro }^{42}\end{array}$ & 2009 & Essay & $\begin{array}{l}\text { Description of arguments pro and con food marketing regulation expressed } \\
\text { by diverse actors in Brazil, defending the need for government intervention } \\
\text { regarding the advertisement of processed foods and beverages. }\end{array}$ \\
\hline Bragaglia ${ }^{43}$ & 2010 & Literature review & $\begin{array}{l}\text { Comparative analysis of the regulatory structures on food and beverage } \\
\text { marketing in Spain and Brazil, indicating larger number of specific ethical } \\
\text { norms for marketing directed to children in Spain. }\end{array}$ \\
\hline Carratore $^{44}$ & 2010 & Law analysis & $\begin{array}{l}\text { Analysis of the Law Project 5.921/01, intended to limit the circulation } \\
\text { of children-targeted marketing in television during certain periods of the } \\
\text { day (07:00 to } 21: 00) \text {. Nevertheless, studies have shown that children and } \\
\text { adolescents usually watch television in other periods, that is, the regulation } \\
\text { would probably fail to have any practical effect. }\end{array}$ \\
\hline Gomes et al. ${ }^{45}$ & 2010 & Literature review & $\begin{array}{l}\text { Comparative analysis of the differences in behavior of transnational food } \\
\text { and beverage companies regarding products advertisement in diverse } \\
\text { countries, showing that compliance with ethical rules of advertisement } \\
\text { in developed countries due to firms' strategies to maintain reputation is } \\
\text { dissonant in relation to advertisement practices in developing countries. }\end{array}$ \\
\hline Henriques $^{46}$ & 2010 & Law analysis & $\begin{array}{l}\text { Interpretation of laws prevailing in Brazil referring to food and beverage } \\
\text { advertisement, pointing to effective illegality of marketing strategies } \\
\text { directed to children and lack of efficiency in self-regulation, especially due to } \\
\text { funding provided by the own regulated industry. }\end{array}$ \\
\hline Lemos et al. ${ }^{47}$ & 2010 & Descriptive study & $\begin{array}{l}\text { Analysis of evolution patterns in food and beverage advertisements } \\
\text { denounced to CONAR between } 1998 \text { and 2009, indicating increasing } \\
\text { volume of ethical transgressions in advertisements of alcoholic beverages } \\
\text { and processed foods. Adoption of self-regulatory models for food and } \\
\text { beverage advertisements seemed insufficient to restrain the adoption of } \\
\text { deceptive and/or abusive contents. }\end{array}$ \\
\hline $\begin{array}{l}\text { Santos and } \\
\text { Batalha }{ }^{48}\end{array}$ & 2010 & Qualitative study & $\begin{array}{l}\text { Analysis of the contents of food advertisement aired in three open TV } \\
\text { channels with high audience between with high audience between August } \\
\text { and September } 2006 \text { in the city of Sao Carlos (state of Sao Paulo, Brazil), } \\
\text { showing that TV advertisements focus on children and women, emphasizing } \\
\text { affective characteristics and lacking information on nutritional value. }\end{array}$ \\
\hline Silva ${ }^{49}$ & 2010 & Essay & $\begin{array}{l}\text { Analysis of the history of marketing directed to infant audience in Brazil, its } \\
\text { language and potential effects on children's perception, selecting diverse } \\
\text { advertisements for analysis in relation to specific regulation related to } \\
\text { advertisement, consumer rights and children. }\end{array}$ \\
\hline Marins et al. ${ }^{50}$ & 2011 & Qualitative study & $\begin{array}{l}\text { Analysis of } 20 \text { advertisements on food and beverages published from June } \\
\text { to October } 2006 \text { in newspapers and magazines, calling for wider discussion } \\
\text { on marketing strategies due to identification of advertisements that } \\
\text { disregard consumers' needs for information on nutritional aspects. }\end{array}$ \\
\hline Reis et al. ${ }^{51}$ & 2011 & Literature review & $\begin{array}{l}\text { Analysis of literature on regulation of food and beverage advertisements } \\
\text { in diverse countries, showing that there are usually legal restrictions } \\
\text { for TV advertisement. In Brazil, regulation proposals and law projects } \\
\text { recommended banning advertisement directed to children during certain } \\
\text { hours. }\end{array}$ \\
\hline Henriques et al. ${ }^{52}$ & 2012 & Qualitative study & $\begin{array}{l}\text { Analysis of food and beverage advertisements directed to children aired } \\
\text { in two TV channels in July } 2008 \text {, showing that } 100 \% \text { of advertisements } \\
\text { included transgressions in at least three clauses proposed in the Brazilian } \\
\text { Public Consultation } 71 / 2006 \text {. }\end{array}$ \\
\hline
\end{tabular}


Chart 1. continuation

\begin{tabular}{|c|c|c|c|}
\hline Title & Year & Method & Findings \\
\hline Prado et al..$^{53}$ & 2012 & Essay & $\begin{array}{l}\text { Analysis of documents related to regulation on food and beverage } \\
\text { advertisement directed to children, indicating that several studies point to } \\
\text { negative impacts on children's eating behavior and that diverse countries } \\
\text { adopt restrictions to marketing for children. }\end{array}$ \\
\hline Teixeira et al. ${ }^{54}$ & 2012 & Literature review & $\begin{array}{l}\text { Analysis of } 27 \text { studies published between } 2000 \text { and } 2012 \text { on initiatives to } \\
\text { support and protect healthy eating implemented in Brazil, concluding that } \\
\text { the country needs regulation for promotion of healthy food consumption. }\end{array}$ \\
\hline Pain and Reinert ${ }^{55}$ & 2013 & Qualitative study & $\begin{array}{l}\text { Analysis of three case studies of food advertisement directed to children, } \\
\text { in order to discuss regulation of food marketing in Brazil, highlighting that } \\
\text { none of the advertisements examined included nutritional information or } \\
\text { explanations on potential benefits or risks to health. }\end{array}$ \\
\hline $\begin{array}{l}\text { Pelegrini and } \\
\text { Schiavo }^{56}\end{array}$ & 2013 & Essay & $\begin{array}{l}\text { Study of recent aspects involving the regulation of advertisement in } \\
\text { Brazil, especially the role of social actors exerting political pressure for } \\
\text { governmental rejection of proposals for regulation of food advertisement } \\
\text { directed to children, pointing to cultural trends towards submission and } \\
\text { restriction to citizenship in the country. }\end{array}$ \\
\hline Burlandy et al. ${ }^{57}$ & 2014 & Literature review & $\begin{array}{l}\text { Review of literature published between } 2000 \text { and 2014, highlighting the } \\
\text { conflicts and interests of public and private sectors involved in initiatives } \\
\text { related to food and nutrition within intersectoral proposals to address the } \\
\text { challenges posed by chronic non-communicable diseases in Brazil. }\end{array}$ \\
\hline Henriques et al. ${ }^{58}$ & 2014 & Law analysis & $\begin{array}{l}\text { Comparative analysis of the proposal extracted from the Brazilian Public } \\
\text { Consultation 71/2006 in relation to the Resolution of Executive Board of } \\
\text { ANVISA (RDC 24/2010), indicating that the original proposal contained } \\
\text { detailed regulation on food and beverage advertisement that were excludec } \\
\text { from RDC } 24 / 2010 \text {. Lobbies from the food and beverage industry and } \\
\text { the media sector may have influenced the final version of the document } \\
\text { approved by the government. }\end{array}$ \\
\hline Rubio and Santos ${ }^{59}$ & 2014 & Descriptive study & $\begin{array}{l}\text { Analysis of the advertisements adjudicated by CONAR in the category of } \\
\text { ethical transgressions related to "children and adolescents" from } 2006 \\
\text { to 2012, showing that CONAR had proactive role in denouncement and } \\
\text { punishment of transgressions, favoring the qualitative improvement of } \\
\text { advertisements. }\end{array}$ \\
\hline $\begin{array}{l}\text { Bacardí-Gascón and } \\
\text { Jiménez-Cruz }{ }^{60}\end{array}$ & 2015 & Literature review & $\begin{array}{l}\text { Analysis of studies published between } 1986 \text { and } 2015 \text { on regulation of } \\
\text { food and beverage TV advertisement in Latin America and USA, indicating } \\
\text { that there was substantial exposure of children to food and beverage } \\
\text { advertisements in diverse countries, regardless of regulation. Self-regulatory } \\
\text { models adopted in Latin America seemed to be less effective than in } \\
\text { developed countries. }\end{array}$ \\
\hline Vendrame et al. ${ }^{61}$ & 2015 & Qualitative study & $\begin{array}{l}\text { Analysis of five TV beer advertisements based on the revision performed in } \\
2010 \text { on the Code of Ethics of CONAR, showing that health professional } \\
\text { experts and adolescents agreed on the ethical transgressions represented } \\
\text { in the advertisements. The lack of efficacy in self-regulation should be } \\
\text { considered in public policies against alcohol consumption. }\end{array}$ \\
\hline
\end{tabular}

Source: The Authors, based on literature review.

Regarding law analysis, one study argued that ANVISA interventions regarding food and beverage advertisement regulation was out of its jurisdiction ${ }^{41}$, two studies focused on problems of food marketing directed to children ${ }^{44,46}$, and remaining studies exposed differences between proposals and effectiveness of regulation and self-regulation in Brazil ${ }^{36,38,58}$, including a comparison with selfregulation in Canada ${ }^{40}$.

Considering qualitative studies, four studies showed high degree of noncompliance to ethical standards ${ }^{35,37,52,61}$, whilst two studies focused on problems arising from absence of appropriate nutritional information for consumers ${ }^{50,55}$, and the last study analyzed target audience of food advertisements, mostly directed to children and women ${ }^{48}$. 
There were six studies based on literature review; none reporting systematic review of literature, and mostly referring to the role and behavior of food and beverage industry in relation to establishment of government regulation and institutional self-regulation, pointing to potential conflicts of interest due to lobby in creation of laws or bias in process of monitoring food and beverage advertisement ${ }^{43,45,51,54,57,60}$.

Five essays were identified, regarding regulation and self-regulation of food and beverage advertisement in Brazil, concentrating in analysis of historical processes related to public health advocacy and role of social actors regarding health promotion, including food industry interference on government regulation proposals $39,42,49,53,56$.

Finally, there were two descriptive studies based on quantitative analysis of data on ethical transgressions denounced to CONAR: one study referring to ethical transgressions related to food and beverage advertisements ${ }^{47}$, and one study focusing ethical transgressions of advertisements directed to children and adolescents in main categories of products and services ${ }^{59}$.

Major part of studies identified presented approach against food and beverage industry $(n=19$; $70.4 \%)^{35-37,40,43-44,47,49-50,52-61}$; seven presented approach against CONAR monitoring $(25.9 \%)^{36,38,40,46-}$ 48,51 , being three also associated with negative view of industry ${ }^{36,40,47}$; five studies were favorable to government regulation $(18.5 \%)^{36,39,42,52,53}$, being three also against actions of industry $36,52-53$; three studies (11.1\%) criticized government regulation (including ANVISA's RDC 24/2010) ${ }^{41,45,48}$; and two studies approached favorably CONAR monitoring $(7.4 \%)^{44,58}$ whilst maintaining negative view of food and beverage industry.

\section{Discussion}

Significant part of literature reviewed suggests that there is direct responsibility of food and beverage industry regarding serious ethical transgressions in advertisement ${ }^{35-37,40,45,47,50,54,57,58,61}$, especially directed towards children ${ }^{46,48,52,53,55,56,59,60}$. Furthermore, results presented indicate high level of relapse in ethical transgressions of certain sectors of food and beverage industry referring to advertisement practices ${ }^{37,42,47-50,52,55,61}$.

Concerning government regulation and/or institutional self-regulation, studies reviewed have shown general trends in favor of government regulation of food and beverage advertisement related to children and adolescents $36,39,42,53,54$, whereas the role self-regulation performed by CONAR is usually criticized $36,38,40,43,46,49,51$, especially regarding its limitations in punishment of ethical transgressions and potential bias due to conflicts of interest.

It is important to point that majority of studies identified in literature review were published after Public Consultation $71 / 2006^{29}$. Additionally, a significant part of studies referred to the period after approval of RDC $24 / 2010^{30}$.

Revocation of RDC 24/2010 during 2013 may have caused an upsurge of arguments pro and con government regulation on food and beverage advertisements, whilst debate remains unsolved in the field of public health due to ongoing societal demands regarding consumers' protection, particularly regarding awareness of marketing impacts on children's and adolescents' health.

Considering that most ethical transgressions informed to CONAR on food and beverage advertisements are related to alcoholic beverages and processed foods, especially regarding trustworthiness, social responsibility and children/adolescents ${ }^{47}$, there is need of consumers' $/$ citizens' $^{\prime}$ initiatives to tackle the problem of ethical transgressions of food and beverage industry in Brazil.

Evidences collected in literature review showed that adoption of collective actions designed to impose economic burden on unethical behavior of industry usually presented better results in comparison to enforcement of government regulation or application of institutional selfregulation ${ }^{40,43,45,51,60}$. That is, granting laws to support consumers' rights and providing educational attainment for knowledgeable citizenship may promote significant improvements in ethical transmission of information through advertisements. 
Bearing in mind numerous tasks under responsibility of $A N V I S A^{62-64}$ involving health surveillance in frontiers and control of health risks within national territory, the inclusion of additional assignments may represent a liability to the National System for Health Surveillance, instead of bringing improvements in health conditions and welfare gains to Brazilian population. On the other side, allowing mass media communication of misinformation without punishment of ethical transgressions that compromise public health leads to perpetuation of deceptive mechanisms within markets based on unfair competition, especially between interest groups which are unevenly armed with information: industry and consumers.

Furthermore, the literature review performed shows that monitoring advertisement, especially referring to food and beverage industry, may require detailed ruling to guarantee withdrawal of bias during judgment and to endorse application of penalties to ethical transgressions adjudicated; otherwise it will just create a situation willing for lawsuits and court battles ${ }^{65}$.

In general, banning food and beverage advertisements seems likely to occur referring to marketing addressed to children and youngsters ${ }^{46,48,52,53,55,56,59,60}$, due to population concerns directed towards children's health. In 2013, a normative amendment of CONAR Code of Ethics banned advertisements directed to children ${ }^{66}$, including foods, beverages and any products or services targeting children. Nevertheless, it is still possible to identify advertisements that appeal to children and youngsters in television and other media.

In relation to ethical practices involving food and beverage marketing, once problems related to advertisement are solved, it seems that focus of public health advocacy in certain countries has been shifting to proposal of laws related to package labeling of food and beverage, in order to provide full disclosure of information about nutritional characteristics of products, including ingredients added during the production process ${ }^{65}$. Full disclosure policy plays an important role in promoting a disseminated culture of social mobilization ${ }^{40}$ towards establishment of reward for evidence-based industry reputation ${ }^{45}$ that may be able to promote effective incentives for establishment of competitive market environment with firms within food and beverage industry seeking to conquer consumers' preferences through ethical marketing practices.

Regarding limitations of the study, it is important to indicate that none grey literature was included in the literature review; therefore, numerous documents published by government agencies (Brazilian Ministry of Health, ANVISA, and other) and non-governmental organizations (IDEC, Instituto Alana, CONAR, $A B I A$, and other) were excluded from the research.

Although exclusion of grey literature may imply that the synthesis of evidences presented preclude political interests surrounding the subject of self-regulation and regulation of food and beverage advertisement, it also purports that the study deliberately proposed to try to avoid potential interests involved in the pamphlet literature. Granting that it may be virtually impossible to expunge completely conflicts of interests only restraining literature review to focus academic studies, it is usually required that scientific research should declare funding from or support to any parts with interests involved in the issue, being subject to liabilities otherwise, especially legal implications and loss of reputation.

In addition, the scientific literature review presented indicates that major part of the studies analyzed opposed the behavior of food and beverage industry regarding advertisement and marketing practices adopted in Brazil, especially targeting children and adolescents. Thus, it seems that there is certain degree of agreement among researchers in diverse fields of knowledge regarding ethical problems pervading sales strategies and commercial conducts of food and beverage industry.

\section{Conclusion}

Literature review performed was designed to join useful information on regulation and selfregulation of food and beverage advertisements in Brazil, seeking to contribute with facts and inputs that may be valuable to progress towards promotion of population welfare and incentive adoption of evidence-based decision-making processes in public health policy in Brazil. 
Scientific evidences gathered in the study indicate that numerous companies within food and beverage industry exhibit differences in ethical behavior depending on location of its businesses, especially regarding practices on its products advertisement, showing lack of commitment or even absence of corporate policy referring to ethical behavior to be adopted in diverse nations worldwide.

In particular, it is important to point that literature review consistently showed problems related to conflicts of interest involving self-regulation. Although few studies indicated that CONAR had role in improvement of quality of advertisement contents, problems arising from its limited authority to impose meaningful punishment on unethical advertisements are acknowledged throughout in Brazilian research on marketing.

Nevertheless, literature also reported limitations on government regulation, especially due to lack of legal support to enforce effective sanctions on unethical advertisement, either because of absence of jurisdiction or due to imperfections in Brazilian legislation related to food and beverage advertisements. However, most studies found in literature review strongly emphasized the importance of regulation in food and beverage advertisements within the interest of public health.

Although there are evidences that consumers' empowerment through education and information may enable self-determination of food and beverage preferences, numerous studies have also shown long-term influence of advertisements directed to children and adolescents in food consumption patterns, indicating precocious capture of affective connections to certain foods and beverages through memory.

In sum, there seems to be sufficient evidences on the need for government regulation of food and beverage advertisements addressed to children and adolescents, complementarily to institutional self-regulation, in order to tackle ethical transgressions on food and beverage advertisement in Brazil. Additionally, there should be imposition of rigorous penalties referring to noncompliance in ethical rules and proposition of incentives towards actions promoting public health, in order to comprise an actual system for promotion of public health.

\section{Contributors}

The study was developed through active collaboration between AK and FMS, being both involved in development of the research, active discussion of results, and review and approval of the final version of the manuscript.

\section{Acknowledgements}

The study was supported by graduate scholarship from Coordenação de Aperfeiçoamento de Pessoal de Nível Superior (Capes) of the Brazilian Ministry of Education.

\section{References}

1. World Health Organization. Report of the join WHO/FAO expert consultation: diet, nutrition and the prevention of chronic diseases. Geneva: WHO; 2003.

2. Woodward-Lopez G, Kao J, Ritchie L. To what extent have sweetened beverages contributed to the obesity epidemic? Public Health Nutr. 2010; 14(3):499-509. 
3. Jaime PC, Duran AC, Sarti FM, Lock K. Investigating environmental determinants of diet, physical activity, and overweight among adults in Sao Paulo, Brazil. J Urban Health. 2011; 88(3):567-81.

4. Schreier HMC, Chen E. Socioeconomic status and the health of youth: a multi-level, multi-domain approach to conceptualizing pathways. Psychol Bull. 2013; 139(3):606-54.

5. Bleich SN, Jones-Smith J, Wolfson JA, Zhu X, Story M. The complex relationship between diet and health. Health Aff. 2015; 34(11):1813-20.

6. Mattos MC, Nascimento PCBD, Almeida SS, Costa TMB. Influência de propagandas de alimentos nas escolhas alimentares de crianças e adolescentes. Psicol: Teor Prat. 2010; 12(3):34-51.

7. Boyland EJ, Halford JCG. Television advertising and branding: effects on eating behaviour and food preferences in children. Appetite. 2012; 62:236-41.

8. Costa SMM, Horta PM, Santos LC. Analysis of television food advertising on children's programming on "free-to-air" broadcast stations in Brazil. Rev Bras Epidemiol. 2013; 16(4):976-83.

9. Díaz-Ramírez G, Jiménez-Cruz A, Souto-Gallardo MC, Bacardí-Gascón M. Effect of the exposure to TV food advertisements on the consumption of foods by mothers and children. J Pediatr Gastroenterol Nutr. 2013; 56(1):86-8.

10. Folkvord F, Anschütz DJ, Buijzen M, Valkenburg PM. The effect of playing advergames that promote energy-dense snacks or fruit on actual food intake among children. Am J Clin Nutr. 2013; 97:239-45.

11. Reisch LA, Gwozdz W, Barba G, De Henauw S, Lascorz N, Pigeot I. Experimental evidence on the impact of food advertising on children's knowledge about and preferences for healthful food. J Obes. 2013:408582. doi: 10.1155/2013/408582.

12. Pereira MR. Indo além: o uso do marketing alimentar e nutricional por uma rede de fast-food na Internet. Brasília [thesis]. Brasília: Universidade de Brasília; 2014.

13. Cezar A. The effects of television food advertising on childhood obesity. J Nevada Public Health Assoc. 2008; 5(1):11-4.

14. Connell PM, Brucks M, Nielsen JH. How childhood advertising exposure can create biased product evaluations that persist into adulthood. J Consum Res. 2014; 41(1):119-34

15. Conselho Nacional de Autorregulamentação Publicitária (CONAR). Código Brasileiro de Autorregulamentação Publicitária. São Paulo: CONAR; 1980.

16. Veiga EM, Pannunzio MIM, Cunha TRD, Garrafa V. A legitimidade da intervenção estatal na publicidade de produtos sujeitos à vigilância sanitária. Rev Direito Sanit. 2011; 2(12):91-111.

17. Harris JL, Sarda V, Schwartz MB, Brownell KD. Redefining "child-directed advertising" to reduce unhealthy television food advertising. Am J Prev Med. 2013; 44(4):358-64.

18. Ohri-Vachaspati P, Isgor Z, Rimkus L, Powell LM, Barker DC, Chaloupka FJ. Childdirected marketing inside and on the exterior of fast food restaurants. Am J Prev Med. 2015; 48(1):22-30.

19. Conselho Nacional de Autorregulamentação Publicitária (CONAR). Anexo " $A$ " do Código Brasileiro de Autorregulamentação Publicitária - Bebidas Alcoólicas. São Paulo: CONAR; 2008.

20. Conselho Nacional de Autorregulamentação Publicitária (CONAR). Anexo "H" do Código Brasileiro de Autorregulamentação Publicitária - Alimentos, Refrigerantes, Sucos e Bebidas Assemelhadas. São Paulo: CONAR; 2006. 
21. Conselho Nacional de Autorregulamentação Publicitária (CONAR). Anexo " $P$ " do Código Brasileiro de Autorregulamentação Publicitária - Cervejas e Vinhos. São Paulo: CONAR; 2008.

22. Conselho Nacional de Autorregulamentação Publicitária (CONAR). Anexo " $T$ " do Código Brasileiro de Autorregulamentação Publicitária - Ices e Bebidas Assemelhadas. São Paulo: CONAR; 2008.

23. Conselho Nacional de Autorregulamentação Publicitária (CONAR). Novas Normas Éticas do Código Brasileiro de Autorregulamentação Publicitária - Publicidade de produtos destinados a crianças e adolescentes. São Paulo: CONAR; 2006.

24. Conselho Nacional de Autorregulamentação Publicitária (CONAR). Resolução 01/08 Anexo "A". São Paulo: CONAR; 2008.

25. Conselho Nacional de Autorregulamentação Publicitária (CONAR). Resolução 02/08 Anexo "P". São Paulo: CONAR; 2008.

26. Conselho Nacional de Autorregulamentação Publicitária (CONAR). Resolução 03/08 Anexo "T". São Paulo: CONAR; 2008.

27. Lei 8.078, de 11 de setembro de 1990. Brasília: Presidência da República; 1990.

28. Valente SBM. Movimentos sociais na publicidade: novos caminhos para a regulamentação da publicidade brasileira? Comunicologia. 2013; 6(1):3-18.

29. Agência Nacional de Vigilância Sanitária (ANVISA). Consulta Pública 71, de 10 de novembro de 2006. Brasília: Ministério da Saúde; 2006.

30. Agência Nacional de Vigilância Sanitária (ANVISA). Resolução RDC 24, de 15 de junho de 2010. Brasília: Ministério da Saúde; 2010.

31. Conselho Nacional de Segurança Alimentar e Nutricional (CONSEA). Recomendação CONSEA 006, de 02 de outubro de 2013. Brasília: CONSEA; 2013.

32. Conselho Nacional dos Direitos da Criança e do Adolescente (CONANDA). Resolução CONANDA 163, de 13 de março de 2014. Brasília: CONANDA; 2014.

33. Agência Nacional de Vigilância Sanitária (ANVISA). Nota técnica conjunta 1, de 29 de junho de 2015. Brasília: Ministério da Saúde; 2015.

34. Moher D, Liberati A, Tetzlaff J, Altman DG, PRISMA Group. Preferred Reporting Items for Systematic Reviews and Meta-Analyses: the PRISMA statement. PLOS Med. 2009; 6(7):1-6.

35. Lopes AS, Montes PR, Silva ET, Ataides NJC, Freitas JS, Araújo MP, et al. Estudo de peças publicitárias de medicamentos e alimentos: as principais legislações infringidas no estado de Goiás. Rev Eletron Farm. 2005; 2 Suppl 2:113-5.

36. Fagundes MJD, Souza RF. A publicidade de alimentos e o direito à saúde. Rev Direito Sanit. 2007; 8(2):34-53.

37. Santos SL, Batalha MO. A ética na propaganda de alimentos: uma análise a partir de comerciais da televisão [Internet]. In: Anais do XLV Congresso da Sociedade Brasileira de Economia Rural (SOBER); 2007; Londrina, Brasil. Brasília: Sociedade Brasileira de Economia Rural; 2007. [citado 18 Jul 2017]. Disponível em: www.sober.org.br/palestra/6/569.pdf.

38. Guimarães CP. Proposta para o monitoramento da propaganda e promoção comercial de alimentos no Brasil [dissertação]. São Paulo: Universidade de São Paulo; 2008.

39. Pinheiro ARO, Carvalho DBB. Estado e mercado: adversários ou aliados no processo de implementação da Política Nacional de Alimentação e Nutrição? Elementos para um debate sobre medidas de regulamentação. Saúde Soc. 2008; 17(2):170-83.

40. Rebouças E. Os desafios para a regulamentação da publicidade destinada a crianças e adolescentes: soluções canadenses e reticências à brasileira. Intercom. 2008; 31(2):75-97. 
41. Ferraz Junior TS. Competência da ANVISA e a regulamentação da propaganda. Rev Direito Adm. 2009; 251:215-32.

42. Monteiro CA, Castro IRR. Por que é necessário regulamentar a publicidade de alimentos. Ciênc Cult. 2009; 61(4):56-9.

43. Bragalia AP. Atualizando o debate sobre o cenário normativo publicitário ante o público infantil: um estudo comparativo entre Brasil e Espanha. Rev Estud Comun. 2010; 11(25):135-44.

44. Carratore LRRD. A legislação sobre a publicidade infantil e a falta de critérios técnicos em mídia [Internet]. In: Anais do Intercom - Sociedade Brasileira de Estudos Interdisciplinares da Comunicação e XI Congresso de Ciência da Comunicação na Região Nordeste; 2010; Campina Grande, Brasil. São Paulo: Sociedade Brasileira de Estudos Interdisciplinares da Comunicação; 2010 [citado 18 Jul 2017]. Disponível em: http:// www.intercom.org.br/papers/regionais/nordeste2010/resumos/R23-1593-1.pdf.

45. Gomes FDS, Castro IRR, Monteiro CA. Publicidade de alimentos no Brasil: avanços e desafios. Ciênc Cult. 2010; 62(4):48-51.

46. Henriques IVM. Controle social e regulação da publicidade infantil: o caso da comunicação mercadológica de alimentos voltada às crianças brasileiras. Rev Eletron Comun Inf Inov Saúde. 2010; 4(4):72-84.

47. Lemos AR, Crescitelli E, Sarti FM. Um estudo exploratório sobre a postura ética das empresas na divulgação de produtos alimentícios [Internet]. In: Anais dos XIII Seminários em Administração (SEMEAD); 2010; São Paulo, Brasil. São Paulo: Departamento de Administração da Faculdade de Economia, Administração e Contabilidade da Universidade de São Paulo; 2010 [citado 18 Jul 2017]. Disponível em: http://sistema.semead.com. $\mathrm{br} / 13 \mathrm{semead} / \mathrm{resultado} /$ an_resumo.asp?cod_trabalho $=290$.

48. Santos SL, Batalha MO. Propaganda de alimentos na televisão: uma ameaça à saúde do consumidor? Rev Admin. 2010; 45(4):373-82.

49. Silva DV. Publicidade infantil na TV: estudo da produção e regulamentação. Temática. 2010; 6(9):1-91.

50. Marins BR, Araújo IS, Jacob SC. A propaganda de alimentos: orientação, ou apenas estímulo ao consumo? Ciênc Saúde Coletiva. 2011; 16(9):3873-82.

51. Reis CEG, Vasconcelos IAL, Barros JFN. Políticas públicas de nutrição para o controle da obesidade infantil. Rev Paul Pediatria. 2011; 29(4):625-33.

52. Henriques P, Sally EO, Burlandy L. Regulamentação da propaganda de alimentos infantis como estratégia para a promoção da saúde. Ciênc Saúde Coletiva. 2012; $17(2): 481-90$.

53. Prado RADP, Acevedo CR, Lopes EL, Moretti SLA. Silva MA. Propaganda televisiva para crianças: um ensaio teórico sobre sua regulamentação nacional e internacional. Rev Admin UEG. 2012; 3(2):84-105.

54. Teixeira MG, Pereira TSS, Silva TSD, Molina MDCB. Medidas de proteção na promoção de alimentação saudável: uma revisão de literatura. Rev Bras Pesqui Saúde. 2012; 14(4):90-6.

55. Pain GKB, Reinert M. Regulamentação versus auto-regulamentação publicitária: uma análise institucional aplicada ao mercado de alimentos infantis. Rev Econ Adm. 2013; 12(2):217-32.

56. Pelegrini $M$, Schiavo SF. Participação popular na mídia é censura? In: Sousa $H$, Pinto M, Fidalgo J, Jedrzejewski S, Costa e Silva E, Melo A, et al. Media policy and regulation: activating voices, illuminating silences. Minho: Centro de Estudos de Comunicação e Sociedade; 2013. p. 378-87. 
57. Burlandy L, Gomes FS, Carvalho CMP, Dias PC, Henriques P. Intersetorialidade e potenciais conflitos de interesse entre governos e setor privado comercial no âmbito das ações de alimentação e nutrição para o enfrentamento de doenças crônicas não transmissíveis. Vig Sanit Debate. 2014; 2(4):124-9.

58. Henriques $P$, Dias PC, Burlandy L, Beiler RM. A regulamentação da propaganda de alimentos no Brasil: convergências e conflitos de interesses. Cad Saúde Pública. 2014; 30(6):1219-28.

59. Rubio FL, Santos FA. Anúncios julgados pelo (CONAR) Conselho Nacional de Autorregulamentação Publicitária, na categoria 'crianças e adolescentes', no período de 2006 a 2012. Rev Inov Tecnol. 2014; 4(2):87-108.

60. Bacardí-Gascón M, Jiménez-Cruz A. TV food geared to children in Latin-American countries and Hispanics in the USA: a review. Nutr Hosp. 2015; 31(5):1928-35.

61. Vendrame A, Silva R, Xuan Z, Sparks R, Noel J, Pinsky I. Self-regulation of beer advertising: a comparative analysis of perceived violations by adolescents and experts. Alcohol Alcohol. 2015; 50(5):602-7.

62. Decreto 3.029, de 16 de abril de 1999. Brasília: Presidência da República; 1999.

63. Lei 9.782, de 26 de janeiro de 1999. Brasília: Presidência da República; 1999.

64. Agência Nacional de Vigilância Sanitária (ANVISA). RDC 61, de 03 de fevereiro de 2016. Brasília: Ministério da Saúde; 2016.

65. Pomeranz JL. Outstanding questions in First Amendment Law related to food labeling disclosure requirements for health. Health Aff. 2015; 34(11):1986-92.

66. Conselho Nacional de Autorregulamentação Publicitária (CONAR)/Associação Brasileira de Anunciantes (ABA). Advertisement and children: global comparative of the legislation and self-regulation [Internet]. São Paulo: CONAR/ABA; 2013 [citado 12 Abr 2016]. Disponível em: http://www.conar.org.br/advertisementandchildren.pdf.

Kassahara A, Sarti FM. Publicidad de alimentos y bebidas en Brasil: revisión de la literatura científica sobre regulación y auto-regulación de propagandas. Interface (Botucatu). 2018; 22(65):589-602.

Los efectos de estrategias de marketing para promoción de alimentos y bebidas se han investigado debido a los potenciales impactos sobre elecciones alimenticias poblacionales, particularmente entre niños y adolescentes. El artículo presenta una revisión de la literatura académica sobre regulación y auto-regulación de propagandas de alimentos y bebidas en Brasil, con base en una búsqueda realizada en bases de datos electrónicas. La mayoría de los estudios identificados se refería al análisis de la legislación o estudio cualitativo de las propagandas. Hay evidencias de la necesidad de regulación de las propagandas dirigidas a niños y adolescentes en complementación al sistema de auto-regulación institucional para el combate a las transgresiones éticas identificadas en propaganda de alimentos y bebidas en Brasil. Adicionalmente, hay la necesidad de aplicación de penalidades severas para transgresiones éticas, así como incentivos a las acciones de apoyo a la alimentación saludable para componer un sistema efectivo de promoción de la salud pública.

Palabras clave: Publicidad de alimentos. Regulación y fiscalización en salud. Publicidad directa al consumidor.

Submitted in 11/07/16. Approved in 07/07/17. 